Firat University Journal of Experimental and
Computational Engineering

\title{
Obtaining and modeling the relaxation modulus of self-healing asphalt mixtures
}

\author{
Kendini iyileştiren asfalt karışımlarının rölaksasyon modüllerinin elde edilmesi ve \\ modellenmesi
}

\author{
Bahadır YILMAZ1 ${ }^{1}$, Ahmet Münir ÖZDEMİ ${ }^{2 *}$ \\ ${ }^{1,2}$ Civil Engineering, Engineering and Natural Sciences, Bursa Technical University, Bursa, Turkey. \\ bahadir.yilmaz@btu.edu.tr, ${ }^{2}$ ahmet.ozdemir@btu.edu.tr
}

Research Article

\begin{abstract}
In this study, pure and self-healing asphalt mixture samples were obtained by adding capsules containing waste vegetable oil to mixtures at $0.25,0.50,0.75$ and $1.00 \%$ ratios. Afterwards, creep test with a constant stress was carried out on the samples, and the resistance of asphalt mixtures against permanent deformation was investigated. Relaxation modulus values were obtained by using the creep compliance values that measured at the end of the experiment with mathematical transformations. Then, the relaxation modulus results were fitted to the Generalized Maxwell Model, which is a common model used to represent the viscoelastic properties of asphalt mixtures, and Prony series parameters were obtained. The results showed that the addition of capsule reduced the permanent deformation strength of the asphalt mixture. In addition, the curve fitting processes were successfully performed and the desired parameters were obtained with high accuracy.
\end{abstract}

Keywords: Asphalt, Microcapsule, Waste vegetable oil, Relaxation modulus, Generalized Maxwell Model

\section{Özet}

Bu çalışmada atık bitkisel yağ içeren kapsüller $0.25,0.50,0.75$ ve $1.00 \%$ oranlarında asphalt karışımlara ilave edilerek, saf ve kapsüllü olmak üzere numuneler elde edilmiştir. Daha sonra elde edilen numuneler üzerinde sabit bir gerilme değerinde sünme deneyi gerçekleştirilerek, kapsül ilavesinin asfalt karışımların kalıcı deformasyona karşı dayanımları incelenmiştir. Deney sonucu ölçülen sünme uyumu değerlerinden, matematiksel dönüşümlerden faydalanılarak gevşeme modülü değerleri elde edilmiştir. Daha sonra gevşeme modülü sonuçları, asfalt karışımların viskoelastik özelliklerini temsil etmek için kullanılan yaygın bir model olan Genelleștirilmiș Maxwell Modeli’ne eğri uydurma yöntemi ile uydurularak Prony serisi parametreleri elde edilmiştir. Sonuçlar, kapsül ilavesinin asfalt karışımının kalıcı deformasyon dayanımını düşürdüğünü göstermiştir. Ayrıca eğri uydurma işlemleri başarıyla gerçekleştirilerek yüksek doğrulukta istenilen parametreler elde edilmiştir.

Anahtar kelimeler: Asfalt, Mikrokapsül, Atık bitkisel yağ, Gevşeme modülü, Genelleştirilmiş Maxwell Modeli

\section{Introduction}

In asphalt mixtures, bitumen undertakes the task of binding the materials in the mixture, and aggregates undertake the task of forming the skeleton structure [1]. After the mixture is laid and compacted, the top course of the pavement becomes the wearing course. For this reason, loads and environmental effects can cause significant damage to this course during its service life [2]. Pavement engineers and researchers have done a wide variety of studies to improve the properties of the wearing course [3-8]. The most common application is to modify the bitumen. In this way, resistance against environmental effects and axle loads is strengthened and a bitumen with desired properties is obtained [9-13].

There has been a lot of talk lately about self-healing materials. As a wide variety of building materials are included in the self-healing concept, asphalt mixtures have also been included in this method and many studies have been carried out [1416]. In their study, Garcia-Hernandez and his team aimed to improve the reflection cracks by adding microcapsules to the asphalt mixture [17]. Gomez-Meijide and his team added metal particles to the mixture in order to improve the asphalt

${ }^{*}$ Corresponding author 
mixture by induction heating method and obtained successful results [18]. Yamaç et al. added capsules containing waste vegetable oil to the mastic asphalt mixture and concluded that the encapsulated samples showed $80 \%$ higher recovery than the pure samples [15]. Yalçın achieved improvement by adding waste metals to the asphalt mixture and then subjecting it to microwave heating. It was determined that the self-healing ability increased, but the mechanical properties of the asphalt mixture were negatively affected [19].

In this study, capsules containing waste vegetable oil were added to the asphalt mixture and the creep test was carried out. Then, relaxation modulus values were obtained from the creep compliance values by using mathematical transformation methods. In this way, relaxation property, which is an important concept in determining viscoelastic properties, could also be examined. Then, relaxation modulus values were fitted to the Generalized Maxwell Model, which is a common viscoelastic model known to successfully reflect the properties of viscoelastic materials, and various evaluations were made.

\section{Materials and Method}

Within the scope of the study, it is aimed to create cracks in the mixture, and to repair the cracks by releasing the waste oils in the capsules added to the mixture by breaking the capsules. For this reason, B 50/70 bitumen, which is a pavement grade bitumen with a high consistency, was obtained from TÜPRAŞ Batman refinery in order to determine the improvement more clearly. In the study, limestone (limestone) type crushed stone material obtained from Elazig Karayazi Region was used as aggregate. In the mixture design, the Superpave design method was adhered to. The gradation was given in Table 1 and Figure 1.

Table 1. Aggregate gradation

\begin{tabular}{cccccc}
\hline Sieve size (mm) & \multicolumn{2}{c}{ Percent } & \multicolumn{2}{c}{ Control values } & \multicolumn{2}{c}{ Restricted Area } \\
& passing & Min. & Max. & Min. & Max. \\
\hline $19(3 / 4 ")$ & 100 & 100 & & & \\
$12.5(1 / 2 ")$ & 95 & 90 & 100 & & \\
$9.5(3 / 8$ ") & 88 & & 90 & & \\
4.75 (No. 4) & 65 & & & & \\
2.36 (No. 8) & 35 & 28 & 58 & 39.1 & 39.1 \\
1.18 (No. 16) & 23 & & & 25.6 & 31.6 \\
0.6 (No. 30 & 14 & & & 19.1 & 23.1 \\
0.3 (No. 50) & 10 & & & 15.5 & 15.5 \\
0.15 (No. 100) & 8 & & & & \\
0.075 (No. 200) & 5 & 2 & 10 & & \\
\hline
\end{tabular}




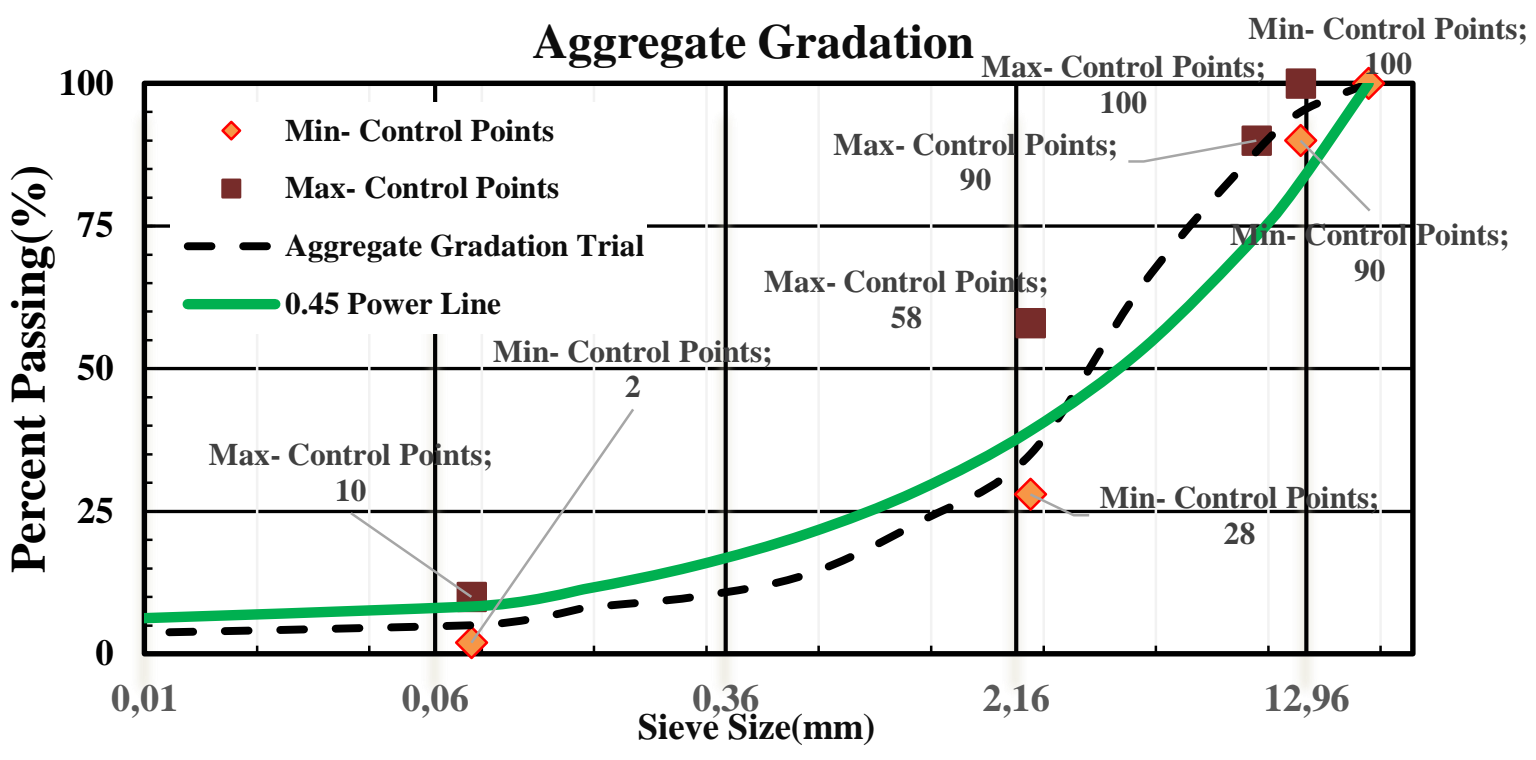

Figure 1. Aggregate gradation

By following the steps and materials in the previous studies in capsule production, capsules containing waste vegetable oil were obtained [15]. The produced capsules were added to the asphalt mixture at the rates of $0.25 \%, 0.50 \%, 0.75 \%$ and $1.00 \%$, and encapsulated mixtures were obtained. The optimum bitumen content was determined as $4.67 \%$.

\subsection{Creep test}

Creep test was carried out to investigate the permanent deformation behavior of pure and encapsulated asphalt mixtures under cyclic loads. Permanent deformation under cyclic loads often results in rutting problem. In the dynamic creep test, a constant load is applied to the surface of the cylindrical sample repeatedly for a certain period of time. With the help of LVDTs adjusted vertically on the metal plate placed on the surface of the sample, plastic and elastic deformations that occur at each load repetition can be detected. The experimental setup inside the air-conditioning cabinet is shown in Figure 2. As a result of the experiment, deformation values are obtained depending on the number of load repetitions. In this experiment, the period is approximately 1 second, so the number of load repetitions can also be considered as the total time. In the study, the experiment was carried out by applying a constant load of $450 \mathrm{kPa}$ at $40^{\circ} \mathrm{C}$.

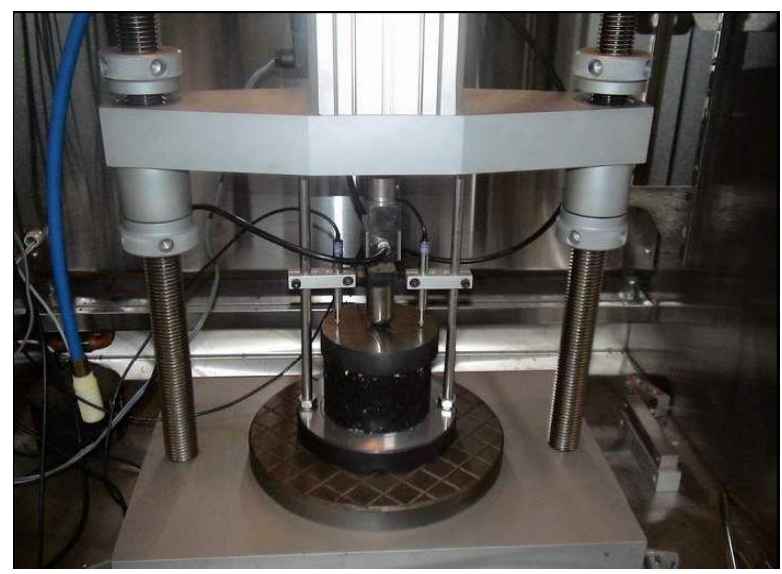

Figure 2. Dynamic creep test

When the time-dependent strain values obtained as a result of the creep test performed under a constant stress $(\sigma 0), \varepsilon(t)$ are divided by the applied constant stress, time-dependent creep compliance values $(\mathrm{J}(\mathrm{t})$ ) will be obtained (Equation 1) [20]. 
$J(t)=\frac{\varepsilon(t)}{\sigma_{0}}$

where $\mathrm{J}(\mathrm{t})$ is the creep compliance at any time $\mathrm{t}(1 / \mathrm{MPa}), \varepsilon(\mathrm{t})$ is the strain at any time $\mathrm{t}$, and $\sigma_{0}$ is the constant stress $(\mathrm{MPa})$.

Then, the creep compliance values obtained were converted to relaxation modulus as in the study of Kim et al. In the aforementioned study, the process was carried out according to the solution proposed by Christiansen [21].

\section{Results}

\subsection{Creep compliance results of asphalt mixtures}

The creep compliance curves of pure and capsule added asphalt mixtures are given in Figure 3.

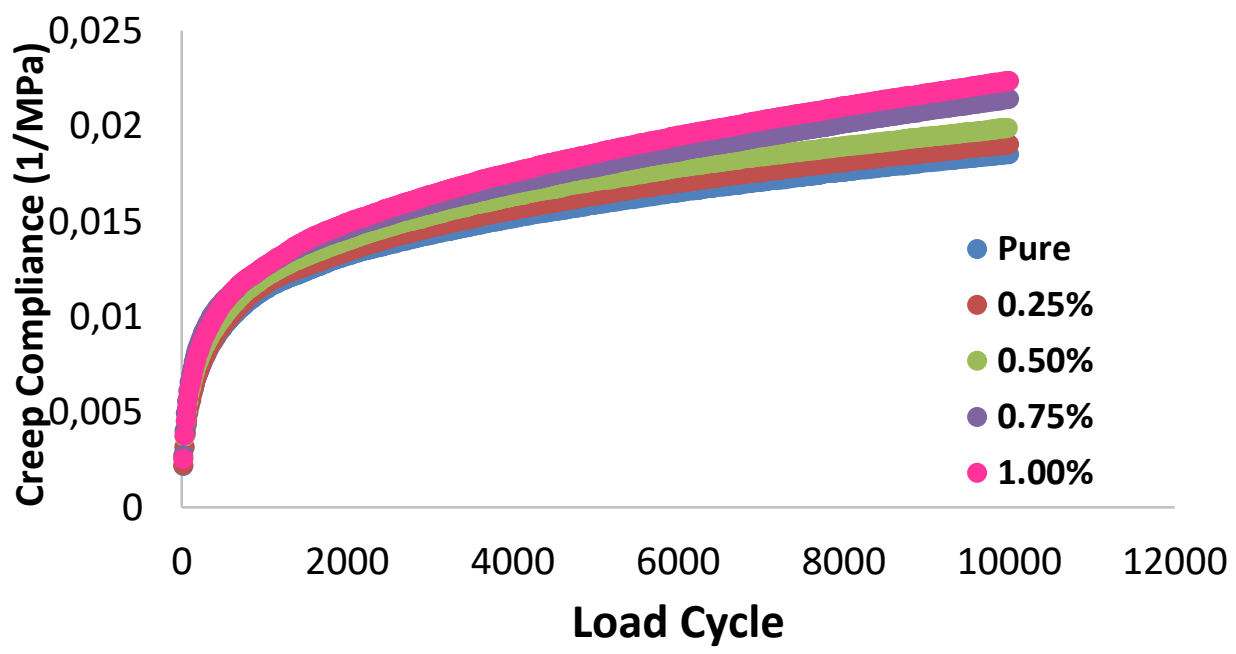

Figure 3. Creep compliance curves of pure and capsule added mixtures

When Figure 3 is examined, a rapid increase was observed in the creep compliance curves in all samples at the beginning, then this curve grows slowly and becomes almost linear. While the mixture with $1.0 \%$ capsule added had the highest creep compliance value, the lowest creep compliance value was obtained in the pure mixture. The reason for this is that as the loading time (number of load repetitions) increases, it releases the oil in the capsule and softens the mixture. Therefore, with the decrease of the creep stiffness, in other words, the creep strength, the creep compliance value increases. Final Creep compliance values increased by $2.81,7.48,15.61$ and $20.77 \%$ for capsule contents $(0.25,0.50,0.75,1.00 \%)$ compared to pure mixture, respectively.

\subsection{Relaxation modulus results of asphalt mixtures}

As mentioned in the method part of the asphalt mixture samples, the relaxation modulus values obtained from the creep compliance results are given in Figure 4. 


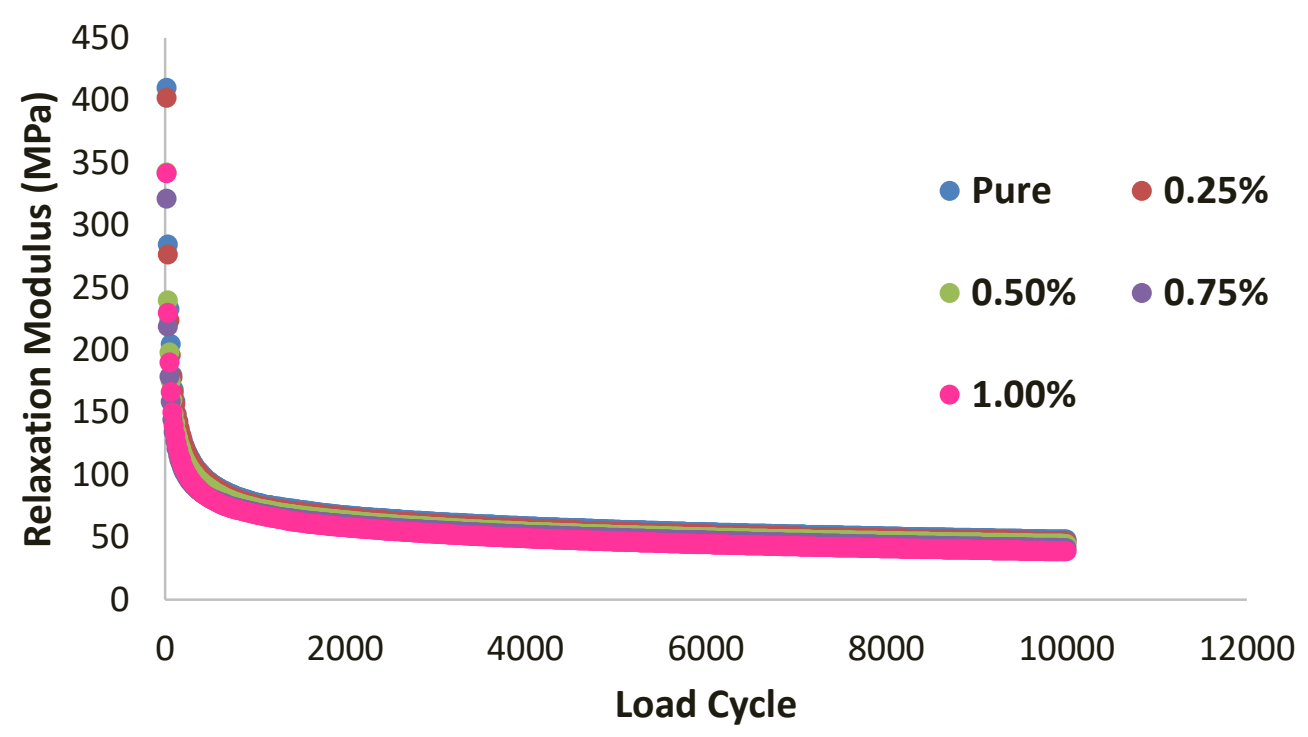

Figure 4. Relaxation modulus curves obtained by the interconversion method

The weakening process of the relaxation modulus, which is an important parameter in defining the viscoelastic behavior, is examined in three stages. In the first stage, the relaxation modulus falls rapidly in a short time and the maximum decrease occurs in this stage. In the second stage, the return of this drop takes place, the rate of fall now slows down and the range it drops is $30 \%$ of the initial stiffness modulus. In the third stage, the relaxation modulus values of the mixture became stable. The amount of decrease at this stage is small. According to Figure 4, it is seen that relaxation modulus values decrease rapidly in all samples. The reason for this is the gradual dissipation of the internal stress in the asphalt mixture. In a subtitle, relaxation modulus values will be fitted to the generalized Maxwell model and these features will be interpreted in more detail. In addition, it is seen that the relaxation modulus values of asphalt mixtures decrease with the increase of the capsule ratio. The final relaxation modulus values were increased by 3.15, 7.34, 14.36 and $19.56 \%$ for the capsule contents $(0.25,0.50,0.75,1.00 \%)$ compared to the pure mixture.

\subsection{Analysis of relaxation behavior of based on Generalized Maxwell Model}

Generalized Maxwell Model was chosen to examine the viscoelastic behavior of asphalt mixture samples in relaxation state. It is known that this model strongly agrees with the relaxation modulus values of viscoelastic materials and successfully represents this behavior. The Generalized Maxwell model equation is given in Equation 2 and the schematic representation of the model is given in Figure 5.

$E(t)=E_{\infty}+\sum_{i=1}^{n} E_{i} e^{-t / \rho_{i}}$

where $\mathrm{E}(\mathrm{t})$ is the relaxation modulus, $\mathrm{E}_{\infty}$ is the equilibrium relaxation modulus, $\mathrm{t}$ is the time, $\rho_{\mathrm{i}}$ is the relaxation $\mathrm{n}$ time.

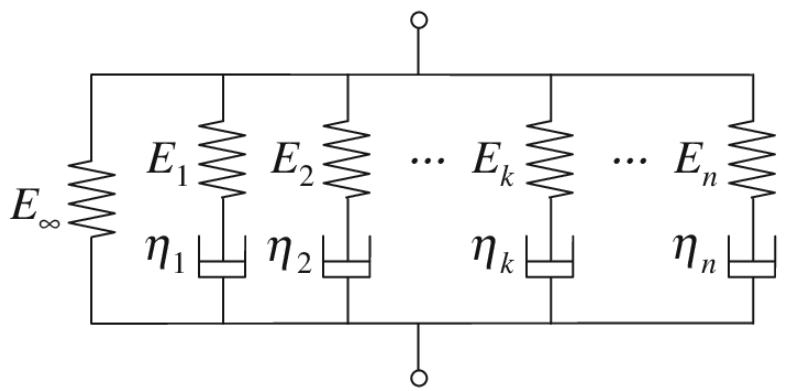

Figure 5. Generalized Maxwell Model [22] 
Prony series fitting parameters of the relaxation modulus of the asphalt mixture was given in Table 2.

Table 2. Prony series results of relaxation modulus

\begin{tabular}{llllll}
\hline & $0 \%$ & $0.25 \%$ & $0.50 \%$ & $0.75 \%$ & $1.00 \%$ \\
\hline E & $3.99 \mathrm{E}+01$ & $2.61 \mathrm{E}+01$ & $2.96 \mathrm{E}+01$ & $2.52 \mathrm{E}+01$ & $3.31 \mathrm{E}+01$ \\
E1 & $2.36 \mathrm{E}+01$ & $5.62 \mathrm{E}+01$ & $3.19 \mathrm{E}+02$ & $7.62 \mathrm{E}+01$ & $2.85 \mathrm{E}+01$ \\
E2 & $9.30 \mathrm{E}+01$ & $4.48 \mathrm{E}+02$ & $5.96 \mathrm{E}+01$ & $3.27 \mathrm{E}+01$ & $3.11 \mathrm{E}+01$ \\
$\mathrm{E} 3$ & $3.09 \mathrm{E}+01$ & $3.16 \mathrm{E}+01$ & $2.01 \mathrm{E}+02$ & $3.13 \mathrm{E}+01$ & $6.18 \mathrm{E}+01$ \\
E4 & $6.39 \mathrm{E}+01$ & $7.12 \mathrm{E}+01$ & $2.67 \mathrm{E}+01$ & $2.82 \mathrm{E}+02$ & $3.19 \mathrm{E}+01$ \\
E5 & $2.03 \mathrm{E}+02$ & $3.35 \mathrm{E}+01$ & $3.95 \mathrm{E}+01$ & $1.02 \mathrm{E}+02$ & $3.11 \mathrm{E}+01$ \\
E6 & $3.84 \mathrm{E}+01$ & $2.68 \mathrm{E}+01$ & $6.40 \mathrm{E}+01$ & $1.65 \mathrm{E}+01$ & $1.98 \mathrm{E}+02$ \\
E7 & $6.94 \mathrm{E}+02$ & $4.18 \mathrm{E}+01$ & $2.84 \mathrm{E}+01$ & $1.06 \mathrm{E}+02$ & $8.21 \mathrm{E}+01$ \\
$R^{2}$ & 0.999 & 0.999 & 0.999 & 0.999 & 0.999 \\
\hline
\end{tabular}

When Table 2 is examined, it is seen that the $\mathrm{R}^{2}$ values in each capsule content are above 0.99 and the fitting process is performed with high accuracy. Because of the Generalized Maxwell Model has too many parameters, it is difficult to obtain a regular variation. For this reason, some fluctuations occurred in the values. However, it has been observed that this model successfully describes the viscoelastic properties of asphalt mixtures, with the successful fitting of the model with high accuracy. In addition, it can be thought that these fluctuations occur because the relaxation modulus values are realized by a mathematical transformation rather than an experimental one.

\section{Discussion}

In this study, pure and self-healing samples were obtained by adding capsules containing waste vegetable oil to asphalt mixtures at $0.25,0.50,0.75$ and $1.00 \%$ ratios. Afterwards, a constant stress value creep test was carried out on the samples obtained, and the resistance of the capsule addition of asphalt mixtures against permanent deformation was investigated. The results obtained are summarized below:

- With the addition of capsule, the permanent deformation strength of the mixture decreased. As the capsule ratio increases, the decrease is greater compared to the pure mixture.

- According to the creep compliance data, it can be said that the rejuvenator in the capsules breaks with the loading and softens the mixture.

-According to the relaxation modulus results, it is seen that the values decrease with the dissipation of the internal stress in the mixture. The mixture containing $1.00 \%$ capsule has the lowest final relaxation modulus.

-Relaxation modulus results were evaluated with the Generalized Maxwell Model. The results showed that relaxation modulus values can be modeled and explained with this model with very high accuracy and low error.

\section{Author Contribution Statement}

In the study, Author 1 contributed to forming the idea, the analysis of the results, provision of the materials and examination of the results; Author 2 contributed making the design, checking the article in terms of content and literature review.

\section{Ethics Committee Approval and Conflict of Interest}

There is no need for an ethics committee approval in the prepared article. There is no conflict of interest with any person/institution in the prepared article. 


\section{References}

[1] Hunter R, Self A, Read J. The Shell Bitumen Handbook, 6th edition. London, England, Shell Bitumen, 2015.

[2] Hu M, Li L, Peng F. "Laboratory investigation of OGFC-5 porous asphalt ultra-thin wearing course". Construction and Building Materials, 219, 101-110, 2019.

[3] Jia H, Chen H, Sheng Y, Meng J, Cui S, Kim YR, et al. "Effect of laboratory aging on the stiffness and fatigue cracking of asphalt mixture containing bamboo fiber". Journal of Cleaner Production, 333, 130120, 2021.

[4] Fu L, Jiao Y, Chen X. "Reinforcement evaluation of different fibers on fracture resistance of asphalt mixture based on acoustic emission technique". Construction and Building Materials, 314, 125606, 2022.

[5] Sun S, Li P, Cheng L, Wang X, Zhang W. "Analysis of skeleton contact stability of graded aggregates system and its effect on slip creep properties of asphalt mixture". Construction and Building Materials, 316, 125911, 2022.

[6]Zhao X, Sheng Y, Lv H, Jia H, Liu Q, Ji X, et al. "Laboratory investigation on road performances of asphalt mixtures using steel slag and granite as aggregate". Construction and Building Materials, 125655, 2021.

[7] Karami M, Nikraz H. "Using advanced materials of granular bra modifier binder to improve the flexural fatigue performance of asphalt mixtures". Procedia Engineering, 125, 452-460, 2015.

[8] Wulandari PS, Tjandra D. "Use of crumb rubber as an additive in asphalt concrete mixture". Procedia Engineering, 171, 1384-1389, 2017.

[9] Apostolidis P, Liu X, Erkens S, Scarpas A. "Evaluation of epoxy modification in bitumen". Construction and Building Materials, 208, 361-368, 2019.

[10] Muhammed Ertugrul Ç, Mehmet Y, Kök BV, Yalçin E. "Effects of various biochars on the high temperature performance of bituminous binder". In Proceedings of 6th Eurasphalt \& Eurobitume Congress. Czech Technical University in Prague, 1-3 June 2016.

[11] Erkuş Y, Kök BV, Yilmaz M. "Effects of graphite on rheological and conventional properties of bituminous binders". International Journal of Pavement Research and Technology, 10(4), 315-321, 2017.

[12] Erkuş Y, Kök BV, Yilmaz M. "Evaluation of performance and productivity of bitumen modified by three different additives". Construction and Building Materials, 261, 120553, 2020.

[13] Vural Kök B, Aydoğmuş E, Yilmaz M, Akpolat M. "Investigation on the properties of new palm-oil-based polyurethane modified bitumen". Construction and Building Materials, 289, 123152, 2021.

[14] Sun D, Sun G, Zhu X, Guarin A, Li B, Dai Z, et al. "A comprehensive review on self-healing of asphalt materials: Mechanism, model, characterization and enhancement". Advances in Colloid and Interface Science, 256, 65-93, 2018.

[15] Yamaç ÖE, Yilmaz M, Yalçın E, Kök BV, Norambuena-Contreras J, Garcia A. "Self-healing of asphalt mastic using capsules containing waste oils". Construction and Building Materials, 270, 121417, 2021.

[16] Norambuena-Contreras J, Liu Q, Zhang L, Wu S, Yalcin E, Garcia A. "Influence of encapsulated sunflower oil on the mechanical and self-healing properties of dense-graded asphalt mixtures". Materials and Structures, 52(4), $78,2019$.

[17] Garcia-Hernández A, Salih S, Ruiz-Riancho I, Norambuena-Contreras J, Hudson-Griffiths R, Gomez-Meijide B. "Self-healing of reflective cracks in asphalt mixtures by the action of encapsulated agents". Construction and Building Materials, 252, 118929, 2020.

[18] Gómez-Meijide B, Ajam H, Lastra-González P, Garcia A. "Effect of air voids content on asphalt self-healing via induction and infrared heating". Construction and Building Materials, 126, 957-966, 2016.

[19] Yalcin E. "Effects of microwave and induction heating on the mechanical and self-healing characteristics of the asphalt mixtures containing waste metal". Construction and Building Materials, 286, 122965, 2021.

[20] Kim YR. Modeling of Asphalt Concrete. Ed: Kim YR New York: McGraw-Hill Education, 2009.

[21] Park SW, Kim YR. "Interconversion between Relaxation Modulus and Creep Compliance for Viscoelastic Solids". Journal of Materials in Civil Engineering, 11(1), 76-82, 1999.

[22] Chae S-H, Zhao J-H, Edwards DR, Ho PS. "Characterization of the Viscoelasticity of Molding Compounds in the Time Domain". Journal of Electronic Materials, 39(4), 419-425, 2010. 